\title{
Osler and the Churg-Strauss Syndrome
}

\author{
J.M.S. Pearce \\ Emeritus Consultant Neurologist, Department of Neurology, Hull Royal Infirmary, Hull, UK
}

\section{Key Words}

Churg-Strauss syndrome • Allergic granulomatous angiitis •

Vasculitis · Osler

\begin{abstract}
This paper records a patient of Osler's, who showed many features compatible with the Churg-Strauss syndrome of allergic granulomatous angiitis to be described 50 years later.

Copyright $\odot 2007$ S. Karger AG, Basel
\end{abstract}

Churg-Strauss syndrome or allergic granulomatous angiitis is a form of systemic vasculitis with eosinophilia [1, 2]. Clinically, it is preceded by asthma, usually accompanied by rhinitis and sinusitis. Neurological symptoms occur in a small number of patients with the Churg-Strauss syndrome, but a cerebrovascular incident, based on vasculitis, is a common cause of death. CNS and renal involvement carry a worse prognosis. Steroids alone are usually adequate for the treatment; cytotoxic drugs are used in the $20 \%$ of patients who fail to respond to steroids.

On 15 October 1900, William Osler presented a case to a meeting of the Johns Hopkins Hospital Medical Society [3], reported as a Case of asthma with cyanosis, extensive purpura, painful muscles, and eosinophilia. It has been suggested [4] that this may be the first reported instance of the Churg-Strauss syndrome.

\section{KARGER}

Fax +41613061234 E-Mail karger@karger.ch www.karger.com
(C) 2007 S. Karger AG, Basel 0014-3022/07/0573-0185\$23.50/0

Accessible online at: www.karger.com/ene
The Mount Sinai Hospital pathologists Jacob Churg (1910-2005) and Lotte Strauss (1913-1985), whilst reviewing 13 autopsied cases diagnosed as polyarteritis nodosa, identified an atypical group in 1951. They reported [5] irregular fever in all cases and marked leukocytosis, as high as $60,000 / \mathrm{ml}$, with up to $84 \%$ eosinophils. Clinical features included recurrent pneumonia, and heart failure, abdominal pain and diarrhoea. There was often haematuria, albuminuria and non-thrombocytopenic purpura. They did not observe myositis. Churg and Strauss found pathologically early tissue eosinophilic infiltrates, and in more advanced cases vasculitis, tissue necrosis and granuloma formation [6].

\section{Osler's Case}

Early diagnosis is difficult (table 1) [7]. Sir William Osler presented his patient to the Johns Hopkins Hospital Medical Society [3], as a case of asthma with cyanosis, extensive purpura, painful muscles and eosinophilia. Warren has suggested [4] that the patient suffered from Churg-Strauss syndrome. Malignant smallpox and trichinosis were worrying differential diagnoses.

Osler's patient was a Polish man who, on 3 October 1890, presented with:

'chills, abdominal pain and vomiting, laboured breathing and very deep cyanosis’ 
Table 1. Diagnostic criteria for Churg-Strauss syndrome

\section{Diagnostic feature}

Asthma

Eosinophilia $>10 \%$

Mononeuropathy multiplex or polyneuropathy

Non-fixed pulmonary infiltrates

Paranasal sinus abnormality; acute or chronic pain, tenderness or opacity

Biopsy showing a blood vessel with extravascular eosinophils

American College of Rheumatology 1990 criteria [7]. Four or more of these 6 criteria yielded a sensitivity of $85 \%$ and a specificity of $99.7 \%$.

\begin{abstract}
'On October 7, in addition to the cyanosis, petechiae appeared over the body, first on the face and chest and then over the skin of the entire body except the legs. He presented a unique appearance, so far as our experience here is concerned, and looked very much like a case of malignant hemorrhagic smallpox. A differential count showed 11 per cent of eosinophiles. On the 8th of October he showed great tenderness of the muscles. The slightest touch on the muscles of the arms or legs caused him to wince. A portion of muscle was excised and showed marked degeneration with a great deal of fat in the fibres, but no trichinae. On the 9th his leucocytosis rose to 52,000 , the petechiae had increased, his face was swollen, and he looked to be in a very critical condition. He was, however, rational, apparently comfortable and took his food fairly well. On the 11th the eosinophiles had risen to 25 per cent. Yesterday the cyanosis began to disappear...'
\end{abstract}

The diagnosis in this patient remains speculative, but Warren made out a persuasive case that this was an example of Churg-Strauss syndrome; if so, this is probably the first recognized report, preceding that of its eponymous authors by 50 years.

\section{Churg-Strauss Syndrome}

Churg-Strauss syndrome or allergic granulomatous angiitis is a form of systemic vasculitis with eosinophilia $[1,2]$. Clinically, it is preceded by asthma, usually accompanied by rhinitis and sinusitis. Rarely there is a preceding history of sensitization to drugs [2]. In most cases progression of symptoms from asthma, upper respiratory tract symptoms, or both, to full-blown eosinophilic vasculitis [8] follows a fairly well-defined course. It affects the CNS in $6-7 \%$ of cases $[9,10]$, but cerebrovascular disease is one of the most common causes of death. There are also cases recorded of primary angiitis of the CNS as- sociated with cerebral amyloid angiopathy [11], probably a distinct disorder.

The illness has 3 phases. The first 'allergic phase' is characterized by asthma, nasal polypi and allergic rhinitis. The second 'eosinophilic phase' presents with chronic eosinophilic pneumonia or eosinophilic gastroenteritis with eosinophilia in the blood and tissue infiltrates. The third phase is a vasculitis, affecting lungs, heart, kidneys, skin or the CNS [12]. Neurological signs relate to a mononeuritis multiplex, symmetrical polyneuropathy, brain infarction or haemorrhage. Death is usually from cardiac or cerebrovascular disease.

Diagnostic criteria suggested [7] are shown in table 1.

Steroids improve survival, with overall remission occurring in about $80 \%$, though $25 \%$ will relapse. With treatment, the 1 -year survival rate is $90 \%$ and the 5 -year survival rate is $62 \%$ [13]. Other immunosuppressants used include cyclophosphamide, or steroids plus cyclophosphamide. Interferon $\alpha$ has been effective in refractory patients.

\section{Mechanism}

Several common features suggest an autoimmunopathy: allergic rhinitis, asthma, positive skin tests, heightened $\mathrm{T}$ cell immunity, altered humoral immunity and vasculitis in the presence of circulating IgE-containing immune complexes. Prolonged eosinophil survival probably plays an important role in its pathogenesis [14]. Hyperresponsiveness to an antigenic stimulus seems to underlie the syndrome. In asthmatics, cysteinyl leukotriene receptor type 1 antagonists are reported to trigger the disease. Antineutrophil cytoplasmic antibodies are positive in only $38 \%$ of cases.

\section{Jacob Churg (1910-2005)}

Churg was born in the Polish city of Dolhinow, then in Russia. His father, Wolf Ravich, was a physician, and his mother, Gita, was a dentist. He graduated in medicine from the university of Wilno in 1933 and subsequently spent 2 years in internship in the departments of internal medicine at the local hospitals. He became an assistant in the pathological department of the university and received his medical doctorate in 1936, but already in the same year the political unrest in Europe caused him to emigrate. He moved to New York, where his uncle, Louis Chargin, was chief dermatologist at the Mount Sinai Hos- 
pital. Churg worked in the bacteriological laboratory and conducted research in the toxicity of various sulphonamides. In 1942 he concentrated on pathology, but his work was interrupted by service during World War II. After returning to civilian life he worked with Lotte Strauss. Churg introduced thin sectioning and special stains, such as chromotrope-aniline blue, in 1956. When it first became available, he applied and developed new techniques for the preparation and examination of renal biopsy tissue for electron microscopy. Churg with his colleagues published many papers on glomerular diseases, studies on lupus nephritis, focal glomerulosclerosis, diabetes mellitus, haemolytic uraemic syndrome, crescentforming glomerulonephritis and amyloidosis. He also investigated and published important studies on asbestosis and mesothelioma. He was appointed clinical professor of pathology in 1966. Before his death, aged 95 years, he had published more than 300 scientific papers and $10 \mathrm{pa}-$ thology textbooks.

\section{Lotte Strauss (1913-1985)}

Lotte Strauss read medicine in Germany and in Siena, Italy, graduating in 1937. She came to the USA in 1938, first working in microbiology at the Beth Israel Hospital in New York, then in pathology, and was trained by Farber, a paediatric pathologist in Boston.

In 1941 she came to the Mount Sinai Hospital, New York, where Paul Klemperer was a major influence and channelled her into a distinguished career in paediatric pathology. She wrote almost 100 scientific papers and trained many paediatric pathologists. In 1966 she was appointed professor at the Mount Sinai Hospital.

She was said to be a warm and exceedingly thoughtful person and a meticulous pathologist. The Lotte Strauss prize was set up by the American Society for Pediatric Pathology.

\section{References}

1 Chumbley LC, Harrison EG, DeRemee RA: Allergic granulomatosis and angiitis (ChurgStrauss syndrome). Mayo Clin Proc 1977;52: 477-484.

2 Lanham JG, Elkon KB, Pusey CD, et al: Systemic vasculitis with asthma and eosinophilia: a clinical approach to the ChurgStrauss syndrome. Medicine (Baltimore) 1984;63:65-81.

3 Osler W: Case of asthma with cyanosis, extensive purpura, painful muscles, and eosinophilia. Bull Johns Hopkins Hosp 1901;12: 17.

4 Warren P: Osler's unusual case - was it Churg-Strauss syndrome? Can Med Assoc J 1999;161:846-847.

5 Churg J, Strauss L: Allergic granulomatosis, allergic angiitis and periarteritis nodosa. Am J Pathol 1951;27:277-294.

6 Lanham JG, Churg J: Churg-Strauss syndrome; in Churg A, Churg J (eds): Systemic Vasculitides. New York, Igaku-Shoin, 1991, pp 101-120.

\footnotetext{
Masi AT, Hunder GG, Lie JT, Michel BA, 10 Noth I, Strek ME, Leff AR: Churg-Strauss Bloch DA, Arend WP, Calabrese LH, Edworthy SM, Fauci AS, Leavitt RY, et al: The syndrome. Lancet 2003;361:587-594. American College of Rheumatology 1990 criteria for the classification of ChurgStrauss syndrome (allergic granulomatosis and angiitis). Arthritis Rheum 1990;33: $1094-1100$.

$\checkmark 8$ Abril A, Calamia KT, Cohen MD: The Churg-Strauss syndrome (allergic granulomatous angiitis): review and update. Semin Arthritis Rheum 2003;33:106-114.

-9 Sehgal M, Swanson JW, DeRemee RA, Colby TV: Neurologic manifestations of ChurgStrauss syndrome. Mayo Clin Proc 1995; 70: 337-341.

1 Scolding NJ, Joseph F, Kirby PA, Mazanti I, et al: Abeta-related angiitis: primary angiitis of the central nervous system associated with cerebral amyloid angiopathy. Brain 2005; 128:500-515.

12 Streho M, Sable-Fourtassou R, Charlotte Brion M, Bourotte I, et al: Churg-Strauss syndrome and pulmonary fibrosis: an unusual association. Presse Med 2006;35(pt 1):1259-1262.

13 Todd DC, Cockcroft DW: Prolonged survival in Churg-Strauss syndrome. Ann Allergy Asthma Immunol 2004;92:92-93.

14 Matsuyama W, Mitsuyama H, Ono M, Shirahama Y, et al: Discoidin domain receptor 1 contributes to eosinophil survival in an NFkappa B dependent manner in Churg-Strauss syndrome. Blood 2006; in press.
} 